\title{
Gastroparese - årsaker, diagnostikk og behandling
}

\begin{abstract}
BAKGRUNN Gastroparese er en motilitetsforstyrrelse i magesekken. Symptomene er uspesifikke, og kvalme og oppkast er de vanligste. Magesmerter, tidlig metthetsfølelse, oppfylthet etter måltider og oppblåst mage er også hyppige plager. Dagens diagnosekriterier krever forsinket ventrikkeltømming uten et påvisbart mekanisk passasjehinder. I denne oversiktsartikkelen belyser vi årsaker, utredning og behandlingsmuligheter.
\end{abstract}

KUNNSKAPSGRUNNLAG Vi har gjort strukturerte artikkelsøk i Embase og PubMed.

RESULTATER En rekke tilstander kan lede til gastroparese. Den hyppigste somatiske årsak er diabetes mellitus. Gastroparese kan også være iatrogent påført i form av operasjoner eller medikamenter. Avgrensningen mot funksjonell dyspepsi kan være vanskelig ved idiopatisk gastroparese. Utredningen er basert på anamnese, gastroskopi og måling av ventrikkeltømmingshastighet. Det er også aktuelt med biokjemiske prøver for differensialdiagnostikk. Behandlingen er hovedsakelig symptomatisk og består av kostholdstiltak, væskebehandling, medikamenter, gastrisk elektrisk nevrostimulator eller endoskopiske og kirurgiske inngrep, som innlegging av sonder for ernæring og avlastning, pylorusplastikk eller gastrektomi.

FORTOLKNING Gastroparese er en alvorlig tilstand som kan ha store konsekvenser for pasientene, med nedsatt livskvalitet, redusert yrkesdeltakelse og stort behov for helsehjelp.

Gastroparese er en alvorlig og underdiagnostisert motilitetsforstyrrelse i magesekken $(1,2)$. Det trengs økt oppmerksomhet om tilstanden. Vi gir her en kortfattet oversikt over diagnostikk og behandling.

De vanligste symptomene ved gastroparese er kvalme og oppkast, mens magesmerter, tidlig metthetsfølelse, oppfylthet etter måltider og oppblåst mage også forekommer hyppig $(3,4)$. Halvparten av pasientene går ned i vekt (4). For å stille diagnosen krever gjeldende retningslinjer verifikasjon av forsinket ventrikkeltømming uten et påvisbart mekanisk passasjehinder $(1,2)$. Imidlertid er sammenhengen mellom ventrikkeltømmingshastigheten og den individuelle symptombyrden ofte svak (5). Det kan derfor komme endringer i retningslinjene, der man i stedet definerer gastroparese som en mer generell nevromuskulær dysfunksjon i magesekken (6).

\section{Kunnskapsgrunnlag}

Vi søkte i databasene Embase og PubMed med søkestrengene gastroparesis AND (epidemiology OR etiology OR diagnosis OR treatment) og * gastric emptying AND measurement (PubMed: «gastric emptying» AND measurement). I Embase identifiserte søkestrengene henholdsvis 1926 og 545 artikler; i PubMed 2082 og 708 artikler - totalt 5261 artikler. Søket ble gjennomført uten tidsavgrensning og ble avsluttet 5.1.2016.

Relevans ble primært vurdert ut fra tittel. Vi ekskluderte artikler der gastroparese eller ventrikkeltømming ikke var hovedtema. Etter denne eksklusjonen satt vi igjen med 2680 artikler. Dernest ble sammendragene vurdert med henblikk på faglig relevans. Kun oversikts- og originalartikler ble inkludert og duplikater ble ekskludert. Dette ga oss 254 artikler, som ble gjennomlest og vurdert.

46 artikler ble til slutt grunnlag for denne kunnskapsoppsummeringen. De ble selektert ut fra vitenskapelig verdi og relevans, basert på forfattergruppens kompetanse og kliniske erfaring.

\section{Prevalens og prognose}

Forekomsten av gastroparese er lite kartlagt, og prevalensen er mye diskutert (7). Det foreligger ingen europeiske prevalenstall. I en populasjonsstudie fant man en aldersjustert prevalens på $0,02 \%$, og fordelingen mellom kvinner og menn var $4: 1$ (3). I en annen studie fant man en estimert prevalens på 1,8\% (8). Dette kan indikere at tilstanden er underdiagnostisert (9).

Gastroparese kan deles i tre alvorlighetsgrader (4). Ved mild gastroparese ( $\operatorname{grad} 1$ ) har pasientene få symptomer og kan spise ordinær kost. Ved kompensert gastroparese ( $\operatorname{grad} 2)$ er symptomene av moderat karakter og pasientene må benytte medikamenter og tilpasse kosten for å holde dem i sjakk. Alvorlig gastroparese ( $\operatorname{grad} 3$ ) omfatter pasienter som har refraktære symptomer og må ernæres parenteralt eller via sonde for å holde vekten oppe.

Konsekvensen for de hardest rammede er store, med nedsatt livskvalitet, redusert arbeidsevne og hyppig kontakt med helsevesenet (10). Symptomene vil ofte variere, det kan være gode og dårlige perioder. $75 \%$ av pasientene vil på et tidspunkt trenge medikamentell behandling, mens $25 \%$ vil

\section{Dag A. Sangnes}

dag.andre.sangnes@helse-bergen.no

Gastroenterologisk seksjon

Medisinsk avdeling

Haukeland universitetssykehus

Eirik Søfteland

Endokrinologisk seksjon

Medisinsk avdeling

Haukeland universitetssykehus

\section{Martin Biermann}

Senter for nukleærmedisin og PET

Radiologisk avdeling

Haukeland universitetssykehus

og

Klinisk institutt 1

Universitetet i Bergen

\section{Odd Helge Gilja}

Nasjonalt senter for gastroenterologisk ultrasonografi

Haukeland universitetssykehus

og

Klinisk institutt 1

Universitetet i Bergen

Hrafnkell Thordarson

Endokrinologisk seksjon

Medisinsk avdeling

Haukeland universitetssykehus

Georg Dimcevski

Gastroenterologisk seksjon

Medisinsk avdeling

Haukeland universitetssykehus

og

Klinisk institutt 1

Universitetet i Bergen

\section{HOVEDBUDSKAP}

Gastroparese er en motilitetsforstyrrelse i magesekken og skyldes som regel diabetes mellitus, kirurgi eller er idiopatisk

De vanligste symptomene er kvalme og oppkast, men mange har magesmerter, tidlig metthetsfølelse, oppfylthet etter måltider og oppblåst mage

Ved diabetisk gastroparese kan debutsymptomet være nyoppståtte problemer med blodsukkerreguleringen 
RAMME 1

Etiologi ved gastroparese, modifisert etter Parkman og medarbeidere (1)

Metabolske og endokrine sykdommer Diabetes mellitus

Hypotyreose

Parathyreoideaforstyrrelser

Addisons sykdom

Gastrointestinale sykdommer

Gastroøsofageal reflukssykdom

Generaliserte forstyrrelser i gastrointestinal motilitet (f.eks. kronisk intestinal pseudoobstruksjon)

Systemiske bindevevssykdommer

Sklerodermi

Systemisk lupus erythematosus

Amyloidose

Nevrologiske sykdommer

Multippel sklerose

Parkinsons sykdom

Muskeldystrofi

Kreftsykdommer (lokalisering)

Oesophagus

Ventrikkel

Pancreas

Lunge

Bryst

Idiopatiske årsaker

Idiopatisk gastroparese

(Postviral gastroparese)

Infeksjoner

Epstein-Barr-virus

Cytomegalovirus

Varicella zoster-virus

Rotavirus

Norovirus

Postoperativ gastroparese

Reflukskirurgi med vagotomi

Nissens fundoplikasjon

Bariatrisk kirurgi

Hjerte-lunge-transplantasjoner

Ablasjonsbehandling for atrieflimmer

Medikamenter

Opioider/opiater

Medikamenter med antikolinerg effekt,

deriblant trisykliske antidepressiva

Kalsiumantagonister

Glukagonlignende polypeptid-1-analoger

Cytostatika

Protonpumpehemmere

$\mathrm{H}_{2}$-reseptorantagonister

Sukralfat

L-dopa

Aluminiumhydroksid

Progesteron

Oktreotid

Rusmidler

Alkohol

Nikotin

Cannabis

Opiater

Øvrige

Kronisk pankreatitt

Kronisk nyresvikt

Mesenteriell iskemi

Total parenteral ernæring

Strålebehandling mot abdomen

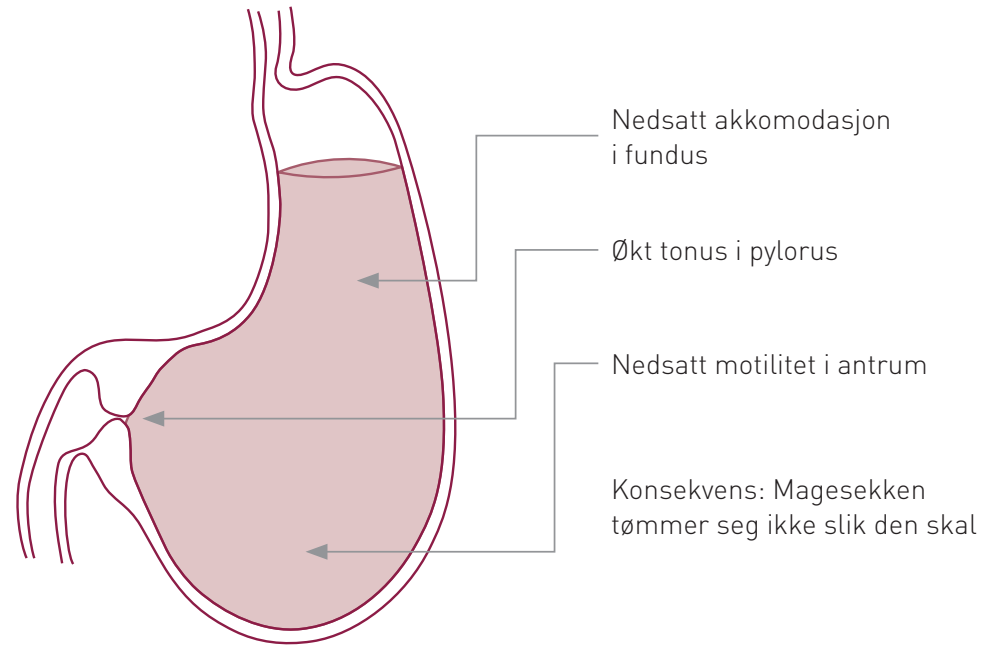

Figur 1 Ved gastroparese kan man blant annet finne nedsatt akkomodasjonsevne i fundus, redusert motilitet i antrum og økt trykk i pylorus

ha behov for endoskopisk eller kirurgisk intervensjon $(3,11)$. En longitudinell studie har vist at magetømmingshastigheten endrer seg lite over en 12-årsperiode (12).

\section{Etiologi}

Hos majoriteten foreligger idiopatisk gastroparese $(3,11)$. I tillegg kan en rekke forhold og tilstander forstyrre magesekkens motilitet og lede til gastroparese (ramme 1, fig 1) $(1,13)$. Vanligst er diabetes mellitus, medikamentbruk, bindevevssykdommer og kirurgiske inngrep (3).

\section{Idiopatisk gastroparese}

Dette er den vanligste formen for gastroparese $(36 \%)(1,2)$. Gjennomsnittlig debutalder er 40 år (14). Symptomene kan komme både akutt og snikende, og utviklingen er ofte lite forutsigbar $(1,14)$. Der pasienter med diabetisk gastroparese er hyppigere plaget med oppkast og brekninger, har pasienter med idiopatisk årsak mer magesmerter, tidlig metthetsfølelse og oppfylthet etter måltider (4). Kvalme er vanligste debutsymptom ved begge tilstander (4).

Det er ofte utfordrende å trekke klare skillelinjer mellom idiopatisk gastroparese og funksjonell dyspepsi (9). Ved funksjonell dyspepsi kan det også være forsinket ventrikkeltømming av mild til moderat grad, mens $90 \%$ av pasientene med idiopatisk gastroparese fyller Roma III-kriteriene for funksjonell dyspepsi $(4,14)$.

\section{Diabetisk gastroparese}

$29 \%$ av gastroparesetilfellene skyldes diabetisk gastroparese $(1,2)$. 30-50\% av dem med langvarig diabetes (type 1 og type 2) har forsinket ventrikkeltømming (15). Kumulativ insidens for gastroparese er $5 \%$ ved diabetes mellitus type 1 og $1 \%$ ved diabetes mellitus type 2 (3). Gastroparese oppstår vanligvis etter at diabetessykdommen har vært etablert i mer enn ti år (16).

For mange pasienter er debutsymptomet økende vansker med blodsukkerreguleringen, særlig i forbindelse med dosering av måltidsinsulin (17). Selv om mild grad av diabetisk gastroparese ikke anses å være progredierende, vil likevel mange pasienter utvikle de klassiske symptomene $(4,12)$.

\section{Postoperativ gastroparese}

Postoperativ gastroparese $(13 \%)(1,2)$ kan oppstå som komplikasjon etter operasjoner i abdomen eller thorax (11). Tidligere så man dette hyppigst etter magesårkirurgi hvor man samtidig gjennomførte vagotomi (1). Etter at man gikk over til medisinsk behandling av magesår, er Nissens fundoplikasjon blitt den ledende årsaken til postoperativ gastroparese $(1,18)$.

Gastroparese er en vanlig komplikasjon ved hjerte-lunge-transplantasjoner og kan også forekomme etter ablasjonsbehandling for atrieflimmer $(19,20)$.

\section{Gastroparese forårsaket av medikamenter} Medikamentbruk er den andre hovedårsaken til iatrogen gastroparese $(1,2)$. Et utall medikamenter kan lede til tilstanden, men de vanligste er opiater, kalsiumblokkere, cytostatika, glukagonlignende polypeptid-1-analoger og midler med antikolinerg effekt, deriblant enkelte trisykliske antidepressiver (1, 2). Seponering av medikamentene vil i de fleste tilfeller reversere gastroparesen.

\section{Andre årsaker}

Infeksjoner, særlig virale, kan gi gastroparese (21). For de fleste vil symptomene 


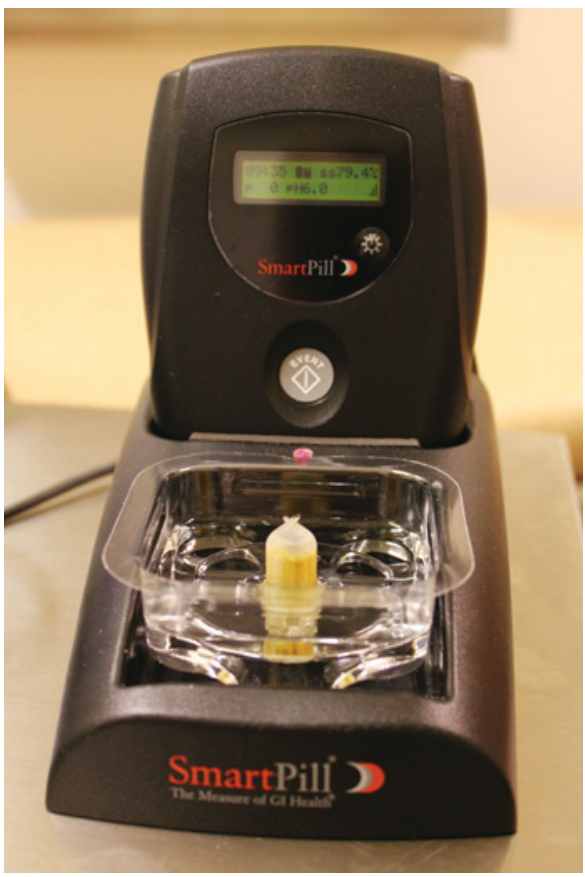

Figur 2 Trådløs motilitetskapsel (Smartpill) og bærbar opptaker. Foto: Dag A. Sangnes

opphøre raskt, men hos enkelte kan symptomer som kvalme, oppkast og tidlig metthet vedvare (22).

Også kreftsykdommer kan gi gastroparese, blant annet som paraneoplastisk fenomen eller gjennom tumorinfiltrasjon i plexus coeliacus, n. vagus eller magesekkens vegg (1).

\section{Diagnostikk}

I tråd med diagnosekriteriene er utredningen basert på symptomkartlegging, gastroskopi og måling av ventrikkeltømmingen $(1,2)$.

\section{Symptomkartlegging}

Diagnostikken starter alltid med en detaljert anamnese, inkludert medisinliste. Vi kartlegger symptomene ytterligere gjennom bruk av forskjellige skjemaer, eksempelvis Gastroparesis Cardinal Symptom Index (GCSI) (23).

\section{Gastroskopi}

Endoskopi brukes for å ekskludere differensialdiagnoser som ulcus, cøliaki og mekanisk obstruksjon som følge av kreft (1).

\section{Måling av ventrikkeltømming}

Ventrikkelscintigrafi regnes som gullstandard. Pasienten spiser et standardmåltid merket med Tc-99m-nanokolloid. Man tar deretter en serie bilder over fire timer. På bakgrunn av referanseverdier for retensjon ved normal ventrikkeltømming kan man vurdere hvorvidt det foreligger forsinket tømming. Etter fire timer regnes $0-10 \%$ retensjon som normalt. $10-15 \%$ retensjon indikerer mild, $15-35 \%$ moderat og $>35 \%$ alvorlig gastroparese (24).

Nylig er det blitt tilgjengelig en trådløs motilitetskapsel som måler $\mathrm{pH}$, temperatur og trykk i hele gastrointestinaltractus (fig 2). Pasienten svelger den sammen med en næringsbar. Kapselen sender signaler til en mottaker som bæres av pasienten i fem døgn. På bakgrunn av målingene kan man beregne transittiden gjennom de ulike gastrointestinale segmentene (fig 3, fig 4). Forsinket ventrikkeltømming defineres som $>5 \mathrm{t}$ fra inntak til kapselen passerer over i duodenum (25).

Ved ${ }^{13} \mathrm{C}$-pustetest spiser pasienten et ${ }^{13} \mathrm{C}$ merket standardmåltid. Dermed kan man utlede ventrikkeltømmingshastigheten ved å måle mengden ${ }^{13} \mathrm{C}$ i utåndingsluften (26).

Ultrasonografi kan også anvendes for å vurdere ventrikkeltømming (27). Ultralydundersøkelse gir også tilleggsopplysninger om kontraktilitet, pylorusfunksjon og akkommodasjon $(28,29)$.

Andre undersøkelser er paracetamolabsorpsjonstest (30) og dynamisk røntgenavbildning etter inntak av røntgentette pelleter (31).

\section{$\emptyset$ vrig diagnostikk}

Biokjemiske prøver er viktig for etablering av etiologi, eksempelvis måling av thyreoideastimulerende hormon (TSH) for å utelukke hypotyreose $(1,2)$. Det er også aktuelt å gjennomføre tester med henblikk på øvrig autonom dysfunksjon, i første rekke hjertefrekvensvariabilitet (32).

\section{Behandling}

Behandling av en eventuell tilgrunnliggende tilstand må være på plass. For pasienter med diabetes mellitus anbefales forbedret glykemisk kontroll $(2,33,34)$. Man bør forsøke å seponere medikamenter som forsinker ventrikkeltømmingen (35).
Behandlingen er basert på et trappetrinnsregime, der målsettingen er best mulig symptomlindring $(1,2)$.

\section{Væsker og ernæring}

Pasientene bør tilstrebe små, hyppige måltider med lavt innhold av fett og fiber (36). De bør være varsomme med alkohol og nikotin og kan ha nytte av å unngå mat og drikke som frigjør $\mathrm{CO}_{2}$ (2). Flytende, kvernet og most mat tømmes lettere fra magesekken (37). Noen har nytte av energirike næringsdrikker for å holde vekten oppe.

Ved uttalte symptomer kan det være nødvendig med sondeernæring eller parenteral ernæring. I de alvorligste tilfellene kan tilstanden kreve sykehusinnleggelse for rehydrering og korreksjon av elektrolyttforstyrrel$\operatorname{ser}(2)$.

\section{Medikamenter}

Anbefalte medikamenter og dosering finnes i tabell 1. Metoklopramid gir både raskere magesekktømming og er kvalmestillende. Mellom 29\% og 53\% opplever symptomlindring $(2,38)$. Domperidon har tilsvarende effekt og gir færre nevrologiske bivirkninger (38). På grunn av risikoen for hjerterytmeforstyrrelser finnes ikke preparatet i Norge, men kan søkes på registreringsfritak (39).

Erytromycin har også god effekt på ventrikkeltømmingen. Bruken begrenses av gastrointestinale bivirkninger, avtakende effekt ved langtidsbruk og induksjon av antibiotikaresistens (2). Erytromycin er en kraftig hemmer av cytokrom P-450-isoenzymer, med tilhørende interaksjonspotensial (40). Preparatet kan også gi forlenget QT-tid (40).

Der hovedproblemet er kvalme, kan antiemetika uten prokinetiske egenskaper brukes, eksempelvis ondansetron, prometazin eller proklorperazin. Er ikke dette tilstrekkelig, kan man forsøke lavdoserte trisykliske antidepressiver med lav antikolinerg effekt, som nortriptylin (2). Andre medikamentalternativer er mirtazapin eller prukaloprid $(33,41)$. Nye medikamenter er under utprøvning (42).

Gastrisk elektrisk nevrostimulator (GES)

Dette gir lavenergisk, høyfrekvent stimulering av magesekken og har vist god sym-

Tabell 1 Anbefalt dosering av utvalgte medikamenter. Tabellen er modifisert etter Camilleri og medarbeidere (2)

$\begin{array}{ll}\text { Medikament } & \text { Anbefalt dosering } \\ \text { Metoklopramid (Afipran) } & 10 \mathrm{mg} \text { peroralt } 10-15 \text { min før måltid. Maks døgndose } 30 \text { mg. Flytende formulering anbefalt } \\ \text { Domperidon (Motilium) } & 10-20 \mathrm{mg} \text { peroralt } \times 3 \text {, ev. tilleggsdose før leggetid } \\ \text { Erytromycin (EryMax/Abboticin) } & 100-250 \mathrm{mg} \text { peroralt } \times 3 . \text { Flytende formulering anbefalt } \\ \text { Ondansetron (Zofran) } & 8 \mathrm{mg}, 1 \text { tablett om morgenen før frokost, ev. } 1 \text { tablett kveld }\end{array}$




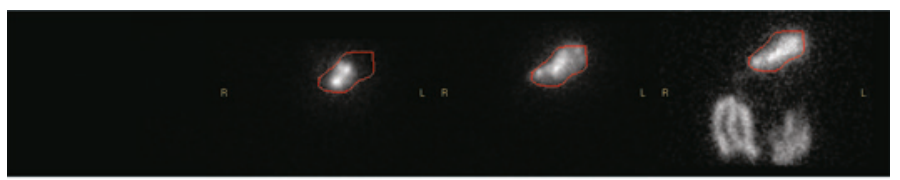

\begin{tabular}{|l|l|l|l|}
\hline Tid & $1 \mathrm{t}$ & $2 \mathrm{t}$ & $4 \mathrm{t}$ \\
\hline Retensjon & $89 \%$ & $78 \%$ & $55 \%$ \\
\hline Normalverdi & $<90 \%$ & $<60 \%$ & $<10 \%$ \\
\hline
\end{tabular}

Figur 3 Illustrasjonen viser ventrikkelscintigrafi hos en pasient med alvorlig diabetisk gastroparese. Vi ser stor aktivitet i magesekken (hvitt område med rød skravering) etter både 1, 2 og 4 timer, noe som indikerer gjenværende mengde radiomerket måltid. Hos pasienten var $55 \%$ av maten igjen i magesekken etter 4 timer, noe som er klart patologisk

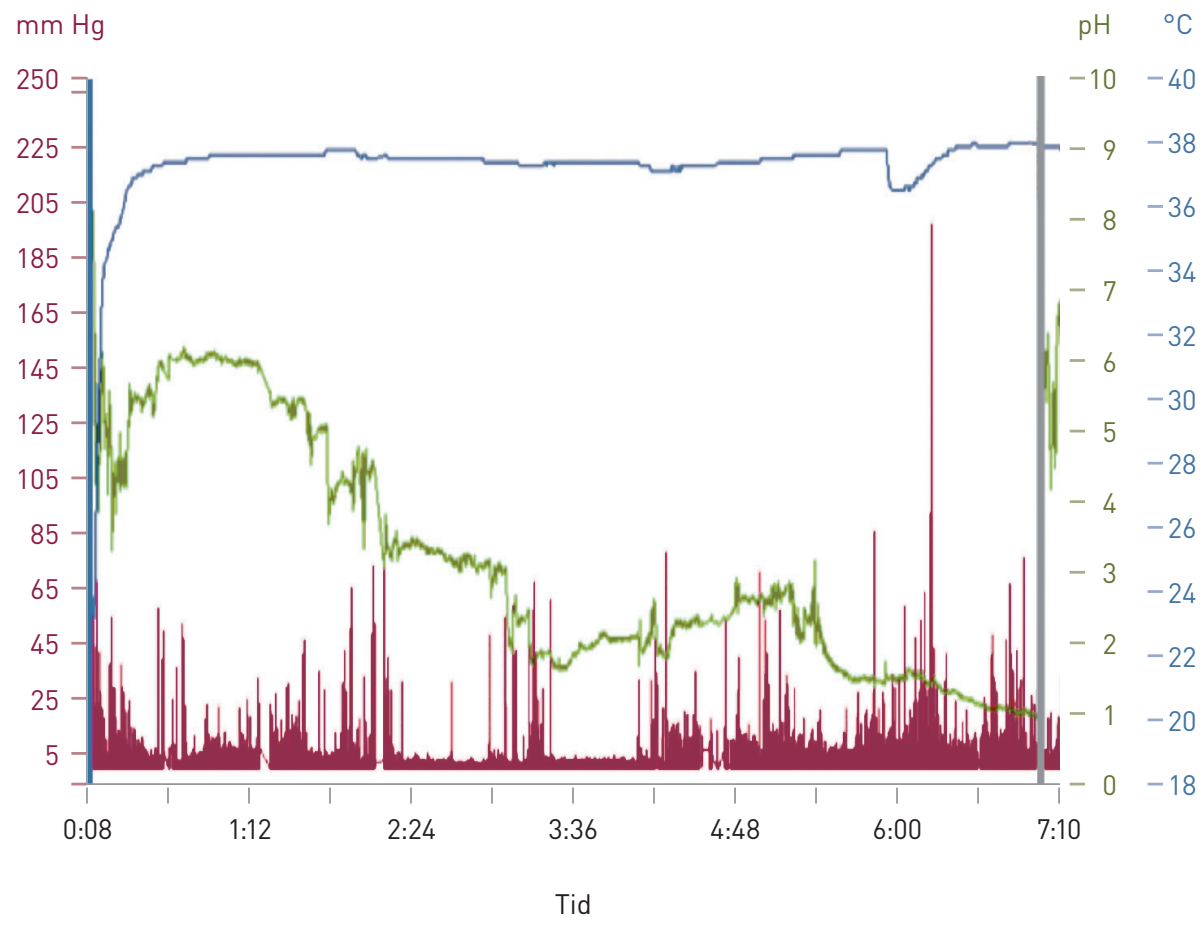

Figur 4 Illustrasjonen viser resultat med trådløs motilitetskapsel hos samme pasient som i figur 3. Vi ser at pH (grønn kurve) faller gradvis, noe som gjenspeiler at måltidet blir gradvis oppløst $i$ den sure magesaften. Etter 6 t 51 min stiger pH-kurven brått til pH 5-6. Dette indikerer at kapselen har passert over i duodenum. Normalverdi for ventrikkeltømming er $<5$ t. Hos pasienten påviste den trådløse motilitetskapselen - i likhet med scintigrafi - alvorlig forsinket tømming

ptomlindrende effekt i åpne studier (2). Resultatene er foreløpig ikke reprodusert i blindede, randomiserte studier (2). Best effekt finner man i gruppen med diabetisk gastroparese (43). I Norge tilbys denne behandlingen ved Haukeland universitetssykehus.

Kirurgisk og endoskopisk intervensjon I sjeldne tilfeller kan det være aktuelt å legge inn gastrostomi for dekompresjon og/eller jejunostomi for ernæring (44). Andre alternativer kan være botoxinjeksjon i pylorus, kirurgisk eller endoskopisk pylorusplastikk - eller i siste instans gastrektomi $(45,46)$.

\section{Diskusjon}

Gastroparese er en underdiagnostisert, alvorlig forstyrrelse i magesekkens motilitet. Tilstanden er karakterisert av symptomer fra øvre gastrointestinaltractus og forsinket ventrikkeltømming. Pasientene har ofte betydelig nedsatt livskvalitet. Tilstanden kan skyldes somatiske sykdommer som diabetes mellitus, være iatrogent påført i form av medikamenter eller kirurgi eller være idiopatisk.

Grundig sykehistorie, gastroskopi og måling av ventrikkeltømmingshastighet er nødvendig for å stille diagnosen. Scintigrafi regnes som gullstandard, mens nye metoder, slik som trådløse motilitetskapsler, gir eks- tra informasjon om motiliteten i hele magetarm-kanalen. Dette kan forhåpentlig belyse den dårlige sammenhengen mellom ventrikkeltømmingshastigheten og alvorlighetsgraden av pasientens plager.

Behandlingen er hovedsakelig symptomatisk. Man følger en trappetrinnsmodell fra kostråd via medikamenter til endoskopiske og kirurgiske inngrep, som innlegging av sonder for ernæring og avlastning, pylorusplastikk eller gastrektomi. Det er sjelden mulighet til kausal behandling, og de færreste pasienter opplever full symptomlindring. Det er derfor viktig med ytterligere forskning innenfor feltet og økt oppmerksomhet om tilstanden.

Dag A. Sangnes (f. 1981)

er lege i spesialisering $\mathrm{i}$ indremedisin og $\mathrm{i}$ fordøyelsessykdommer.

Forfatter har fylt ut ICMJE-skjemaet og oppgir ingen interessekonflikter.

\section{Eirik Søfteland (f. 1974)}

er ph.d., spesialist i endokrinologi og overlege. Forfatter har fylt ut ICMJE-skjemaet og oppgir følgende interessekonflikter: Han har mottatt bidrag fra Diabetesforbundet og fra EUs 7th Framework Programme.

\section{Martin Biermann (f. 1963)}

er førsteamanuensis II ved Universitetet i Bergen, spesialist i nukleærmedisin og overlege. Forfatter har fylt ut ICMJE-skjemaet og oppgir ingen interessekonflikter.

\section{Odd Helge Gilja (f. 1962)}

er spesialist i indremedisin og i fordøyelsessykdommer og professor. Han leder Nasjonalt senter for gastroenterologisk ultrasonografi. Forfatter har fylt ut ICMJE-skjemaet og oppgir ingen interessekonflikter.

\section{Hrafnkell B. Thordarson (f. 1952)}

er spesialist i endokrinologi og seksjonsoverlege.

Forfatter har fylt ut ICMJE-skjemaet og oppgir ingen interessekonflikter.

\section{Georg Dimcevski (f. 1966)}

er ph.d., spesialist i fordøyelsessykdommer og seksjonsoverlege og førsteamanuensis II ved Universitetet i Bergen.

Forfatter har fylt ut ICMJE-skjemaet og oppgir ingen interessekonflikter.

\section{Litteratur}

1. Parkman HP, Hasler WL, Fisher RS. American Gastroenterological Association technical review on the diagnosis and treatment of gastroparesis. Gastroenterology 2004; 127: 1592-622.

2. Camilleri M, Parkman HP. Shafi MA et al. Clinical guideline: management of gastroparesis. Am J Gastroenterol 2013; 108: 18-37 
3. Jung HK, Choung RS, Locke GR et al. The incidence, prevalence, and outcomes of patients with gastroparesis in Olmsted County, Minnesota, from 1996 to 2006. Gastroenterology 2009; 136: 1225-33.

4. Parkman HP, Yates K, Hasler WL et al. Similarities and differences between diabetic and idiopathic gastroparesis. Clin Gastroenterol Hepatol 2011 9: $1056-64$

5. Bharucha AE, Camilleri M, Forstrom LA et al. Relationship between clinical features and gastric emptying disturbances in diabetes mellitus. Clin Endocrinol (Oxf) 2009. 70: 415-20.

6. Pasricha PJ, Parkman HP. Gastroparesis: definitions and diagnosis. Gastroenterol Clin North Am 2015; 44: 1-7.

7. Hasler WL. Geography lessons: scrutinizing stateby-state differences in inpatient gastroparesis care. Dig Dis Sci 2013; 58: 2743-5.

8. Rey E, Choung RS, Schleck CD et al. Prevalence of hidden gastroparesis in the community: the gastroparesis «iceberg». J Neurogastroenterol Motil 2012; 18: 34-42.

9. Stanghellini V, Tack J. Gastroparesis: separate entity or just a part of dyspepsia? Gut 2014; 63: 1972-8.

10. Talley NJ, Young L, Bytzer P et al. Impact of chronic gastrointestinal symptoms in diabetes mellitus on health-related quality of life. Am J Gastroenterol 2001; 96: 71-6.

11. Soykan I, Sivri B, Sarosiek I et al. Demography, clinical characteristics, psychological and abuse profiles, treatment, and long-term follow-up of patients with gastroparesis. Dig Dis Sci 1998; 43 2398-404.

12. Jones KL, Russo A, Berry MK et al. A longitudinal study of gastric emptying and upper gastrointestinal symptoms in patients with diabetes mellitus. Am J Med 2002; 113: 449-55.

13. Hasler WL. Gastroparesis. Curr Opin Gastroenterol 2012: 28: 621-8

14. Parkman HP, Yates K, Hasler WL et al. Clinical features of idiopathic gastroparesis vary with sex, body mass, symptom onset, delay in gastric emptying, and gastroparesis severity. Gastroenterology 2011; 140: 101-15

15. Ma J, Rayner CK, Jones KL et al. Diabetic gastroparesis: diagnosis and management. Drugs 2009; 69: $971-86$

16. Camilleri M, Bharucha AE, Farrugia G. Epidemiology, mechanisms, and management of diabetic gastroparesis. Clin Gastroenterol Hepatol 2011 9: 5-12, quiz e7

17. Kong M-F. Horowitz M, Jones $\mathrm{KL}$ et al. Natura history of diabetic gastroparesis. Diabetes Care 1999: 22: 503-7.

18. Hunter RJ, Metz DC, Morris JB et al. Gastropare- sis: a potential pitfall of laparoscopic Nissen fundoplication. Am J Gastroenterol 1996; 91: 2617-8.

19. Sodhi SS, Guo J-P Maurer AH et al. Gastroparesis after combined heart and lung transplantation. J Clin Gastroenterol 2002; 34: 34-9.

20. Aksu T, Golcuk S, Guler TE et al. Gastroparesis as a complication of atrial fibrillation ablation. Am J Cardiol 2015; 116: $92-7$

21. Bityutskiy LP, Soykan I, McCallum RW. Viral gastroparesis: a subgroup of idiopathic gastroparesis-clinical characteristics and long-term outcomes. Am J Gastroenterol 1997; 92: 1501-4.

22. Oh JJ, Kim CH. Gastroparesis after a presumed viral illness: clinical and laboratory features and natural history. Mayo Clin Proc 1990; 65: 636-42.

23. Revicki DA, Rentz AM, Dubois D et al. Development and validation of a patient-assessed gastroparesis symptom severity measure: the Gastroparesis Cardinal Symptom Index. Aliment Pharmacol Ther 2003; 18: $141-50$

24. Tougas G, Eaker EY, Abell TL et al. Assessment of gastric emptying using a low fat meal: establishment of international control values. Am J Gastroenterol 2000; 95: 1456-62.

25. Saad RJ, Hasler WL. A technical review and clinical assessment of the wireless motility capsule. Gastroenterol Hepatol (N Y) 2011; 7: 795-804.

26. Lee JS, Camilleri M, Zinsmeister AR et al. A valid, accurate, office based non-radioactive test for gastric emptying of solids. Gut 2000; 46: 768-73.

27. Ricci R, Bontempo I, Corazziari E et al. Real time ultrasonography of the gastric antrum. Gut 1993; 34: 173-6.

28. Hausken T, Odegaard S, Berstad A. Antroduodenal motility studied by real-time ultrasonography. Effect of enprostil. Gastroenterology 1991; 100: 59-63

29. Gilja OH, Lunding J, Hausken T et al. Gastric accommodation assessed by ultrasonography. World J Gastroenterol 2006; 12: 2825-9.

30. Medhus AW, Lofthus CM, Bredesen J et al. Gastric emptying: the validity of the paracetamol absorption test adjusted for individual pharmacokinetics. Neurogastroenterol Motil 2001; 13: 179-85.

31. Olausson EA, Brock C. Drewes AM et al. Measurement of gastric emptying by radiopaque markers in patients with diabetes: correlation with scintigraphy and upper gastrointestinal symptoms. Neurogastroenterol Motil 2013; 25: e224-32

32. Søfteland E, Brock C, Frøkjær JB et al. Association between visceral, cardiac and sensorimotor polyneuropathies in diabetes mellitus. J Diabetes Complications 2014; 28: 370-7.

33. Stevens JE, Jones KL, Rayner CK et al. Pathophysiology and pharmacotherapy of gastroparesis: current and future perspectives. Expert Opin Pharmacother 2013; 14: 1171-86.
34. Sharma D, Morrison G, Joseph F et al. The role of continuous subcutaneous insulin infusion therapy in patients with diabetic gastroparesis. Diabetologia 2011; 54: 2768-70

35. Camilleri M, Grover M, Farrugia G. What are the important subsets of gastroparesis? Neurogastroenterol Motil 2012; 24: 597-603.

36. Homko CJ, Duffy F, Friedenberg FK et al. Effect of dietary fat and food consistency on gastroparesis symptoms in patients with gastroparesis. Neurogastroenterol Motil 2015; 27: 501-8.

37. Olausson EA, Störsrud S, Grundin $\mathrm{H}$ et al. A smal particle size diet reduces upper gastrointestinal symptoms in patients with diabetic gastroparesis a randomized controlled trial. Am J Gastroentero 2014; 109: 375-85.

38. Patterson D, Abell T, Rothstein R et al. A doubleblind multicenter comparison of domperidone and metoclopramide in the treatment of diabetic patients with symptoms of gastroparesis. Am J Gastroenterol 1999: 94: 1230-4.

39. Owyang C. Phenotypic switching in diabetic gastroparesis: mechanism directs therapy. Gastroenterology 2011; 141: 1134-7.

40. Larson JM, Tavakkoli A, Drane WE et al. Advantages of azithromycin over erythromycin in improving the gastric emptying half-time in adult patients with gastroparesis. J Neurogastroenterol Motil 2010 16: 407-13.

41. Kim SW, Shin IS, Kim JM et al. Mirtazapine for severe gastroparesis unresponsive to conventional prokinetic treatment. Psychosomatics 2006; 47 440-2.

42. Camilleri M. Pharmacological agents currently in clinical trials for disorders in neurogastroenterology. J Clin Invest 2013; 123: 4111-20.

43. Chu H, Lin Z, Zhong L et al. Treatment of high-frequency gastric electrical stimulation for gastroparesis. J Gastroenterol Hepatol 2012; 27: 1017-26.

44. Fontana RJ, Barnett JL. Jejunostomy tube placement in refractory diabetic gastroparesis: a retrospective review. Am J Gastroenterol 1996; 91 2174-8.

45. Bhayani NH, Sharata AM, Dunst CM et al. End of the road for a dysfunctional end organ: laparoscopic gastrectomy for refractory gastroparesis. J Gastrointest Surg 2015; 19: 411-7

46. McCarty TR, Rustagi T. Endoscopic treatment of gastroparesis. World J Gastroenterol 2015, 21: 6842-9

Mottatt 28.4. 2015, første revisjon innsendt 11.2. 2016, godkjent 29.3. 2016. Redaktør: Inge Rasmus Groote. 